положением тела и изменением скорости вращения, двойные сальто назад в группировке, двойные сальто назад в полугруппировке, двойные сальто назад согнувшись, а так же сальто с поворотами во круг вертикальной оси вращения гимнастки с уверенным приземлением на ноги.

2. Степень владения формирующими действиями на опоре: рондаты, фляки, подготовительные действия движения на опоре для набора скорости перед основными действиями, и вариативным исполнением подготовительных действий; отскоками с различной скоростью и мощностью по высоте и времени исполнения;

3. Степень владения безопорными вращательными движениями типа сальто назад и вперед (в акробатике, на других снарядах, включая батут).

4. Уровень функциональной и специальной физической подготовки, в особенности в расчете на освоение отталкивающих действий на опоре.

В соответствии с результатами проверки в дальнейшем избирается стратегия обучения конкретной гимнастки данному конкретному элементу, включая необходимые предварительные шаги работы, предшествующие углубленному освоению упражнений с фазой полета.

$$
* * *
$$

1. Аркаев, Л.Я. Как готовить чемпионов : Теория и технология подгот. гимнастов высш. квалификации / Аркаев Леонид Яковлевич, Сучилин Николай Георгиевич. - М.: ФиС, 2004. - 326 с.: ил.

2. Артемова, Е.Н. Индивидуализация тренировочного процесса гимнасток в упражнениях на бревне на этапе углубленной специализации / Е.Н. Артемова, А.А. Горелов, Я. Водичар // Вестник спортив. науки. - 2014. - № 4. - С. 19-25.

3. Васильев, О.С. Движение в пространстве, пространство движения и геометрический образ движения: опыт топологического подход SpatialMovementSpaceofMovementandGeometricImageofMovement - ExperienceofTopologicalApproach / Васильев О.С., Сучилин Н.Г. // Теория и практика физ. культуры. - 2004. - № 3. - С. 13-21.

4. Гавердовский Ю.К. Техника гимнастических упражнений :Попул. учеб.пособие / Гавердовский Юрий Константинович. - М.: Терра-спорт, 2002. - 508 с.

5. Гавердовский, Ю.К. Двигательный навык и автоматизация двигательных действий в спорте = Movementskillandmovementactionsautomatizationinsport / Гавердовский Юрий Константинович // Теория и практика прикладных и экстремальных видов спорта. - 2012. - № 1. - С. 46-49.

\title{
Русова П.В. \\ Исследование тенденций развития массового студенческого спорта в российских федеральных университетах
}

Уральский федеральный университет им. Б. Н. Ельцина

doi 10.18411/spc-04-03-2018-16

(Россия, Екатеринбург)

idsp 000001:spc-04-03-2018-16

\section{Аннотация}

В данной статье речь идет об основных тенденциях развития массового студенческого спорта в федеральных университетах Российской Федерации. Автором анализируются основные проблемы развития массового студенческого спорта в российских федеральных университетах, предлагаются возможные направления их решения, а также делается вывод о том, что если Правительство РФ обратит внимание на данную сферу, то российский студенческий спорт, в том числе и спорт высших достижений, сможет представлять собой не только гордость Российской Федерации, но и вполне реальную конкуренцию странам Запада.

Ключевые слова:виды спорта, личность студента, массовый студенческий спорт, Российская Федерация, федеральные ВУЗы. 


\section{Abstract}

In this article we are talking about the main trends in the development of mass student sport in federal universities of the Russian Federation. The author analyzes the main problems of the development of mass student sport in Russian federal universities, suggests possible directions for their solution. Also in this article we have a conclusion that if the Government of the Russian Federation will pays attention to this sphere, then the Russian student sport including the sport of higher achievements can represent not only the pride of the Russian Federation, but also quite real competition to the countries of the West.

Key words: sports, student's personality, mass student sport, Russian Federation, federal universities.

Актуальность исследования по теме данной работы обусловлена тем фактом, что в настоящее время наблюдается тенденция повышения роли высшей школы не только в качестве социального института, который формирует компетентного специалиста, но также и в качестве такого социального института, деятельность которого направлена также и на формирование здоровой личности. На настоящий момент имеет место тенденция признания высшего профессионального образования в качестве одного из приоритетных направлений в том, что касается развития личности студента в рамках всего многообразия жизненных ситуаций. Соответственно, огромная роль в процессе развития и становления личного студента отводится образованию в сфере физической культуры, в рамках которого идет овладение специальными знаниями и способами их рационального применения с целью самосовершенствования.

Соответственно, учитывая вышесказанное, представляется необходимым проанализировать особенности и основные тенденции развития массового студенческого спорта в федеральных университетах Российской Федерации.

Необходимо отметить, что в ВУЗах РФ культивируется более 60 различных видов спорта. В качестве наиболее массовых из них выступают такие, как: бадминтон, баскетбол, бокс, гимнастика, лыжный спорт, легкая атлетика, плавание, отдельные виды спортивных единоборств, спортивный туризм, фехтование, мини-футбол, настольных теннис, шахматы. В свете вышесказанного необходимо также упомянуть о том, что с 1994 года Российским студенческим спортивным союзом проводятся массовые соревнования, в которых принимает участие студенческая и учащаяся молодежь. Такие соревнования получили название Чемпионатов России среди студентов, и они проводятся по 55 различным видам спорта.

21.11.2017 министр спорта РФ П.А. Колобков утвердил Концепцию студенческого спорта в Российской Федерации на период до 2025 года [1], причем в качестве основной цели данной Концепции выступает создание условий, которые бы обеспечивали возможность студентам профессиональных организаций образования, а также профессиональных организаций высшего образования, ведения здорового образа жизни в рамках систематических занятий физкультурой и спортом, получения доступа к развитой спортивной инфраструктуре, равно как и повышения конкурентоспособности физкультуры и спорта в Российской Федерации. Положениями вышеупомянутой Концепции определяется система приоритетных направлений, вектор которых лежит в направлении обеспечениями развития физкультурной, спортивной и оздоровительной работы в рамках деятельности профессиональных образовательных организаций, а также образовательных организаций высшего образования, равно как и студенческого спорта в РФ.

Нельзя сказать, что последнее время студенческий спорт в России отсутствовал и никак не развивался. В каких-то ВУЗах организация учебно-тренировочных процессов была неплоха. Но, в основном, - это хорошо обеспеченные, устоявшиеся учебные заведения, которых совсем немного. Большинство федеральных ВУЗов сталкивается с колоссальной проблемой нехватки спортивных залов, бассейнов, стадионов и прочей инфраструктуры. Главной причиной этого является банальный 
дефицит денежных средств и квалифицированных кадров для их привлечения. Может возникнуть вопрос, зачем ВУЗам вкладывать средства в спорт, если приоритетной задачей является подготовка квалифицированных специалистов, а не мастеров спорта? Однако, студенческий спорт может быть интересным для каждого его участника (студента, ВУЗа, тренера, болельщика, спонсора, СМИ), а система его продвижения эффективной качественной и конкурентоспособной на мировой арене, как показывают результаты созданной в 2011 году Ассоциации Студенческого и Молодёжного Спорта (АСМC), которая имеет множество последователей [4].

В соответствии с данными официальной статистики РФ в период 2015-2016 гг., образовательные услуги в РФ предоставлялись 896 ВУЗами, из которых 530 составляли государственные ВУЗы, а 360 - негосударственные; а также 2891 ССУЗом [6, С.39].

В ВУЗах, которые были приведены выше, на момент проведения исследования проходило обучение 4,7 млн. человек, из них 2,3 млн. студентов по очной форме обучения. Если же говорить о ССУЗах, то в них на момент проведения исследования проходило обучение 2,1 млн. человек, из них - 1,7 млн. студентов, находящихся на очной форме обучения. Кроме того, на момент проведения исследования в Российской Федерации действовало 332 спортивных студенческих клуба [6, С.40].

В рамках данной работы представляется необходимым перечислить также наиболее популярные виды спорта, которым отдает предпочтение большая часть студентов. Так, например, в 2017 году был проведен мониторинг, по итогам которого было выявлено 48 основных видов спорта, пользующихся наибольшей популярностью у студентов. Среди наиболее популярных можно назвать следующие (в \% по количеству занимающихся):

- волейбол - 85\%;

- баскетбол - 80\%;

- настольный теннис - 78\%;

- мини-футбол (муж.) - 75\%;

- легкая атлетика - $65 \%$;

- лыжные гонки - 48\%;

- шахматы - $48 \%$;

- самбо - 43\%;

- фитнес-аэробика - 43\%;

- футбол - 35\% [6, С.42].

Несмотря на огромное разнообразие и широкий диапазон перспективных направлений, сегодня студенческий спорт в своем развитии выделяет несколько стратегических целей. К ним относится: развитие массового спорта, приобщение к регулярным занятиям физической культурой и спортом учащихся образовательных организаций высшего и среднего образования, обеспечение подготовки выступления сборных студенческих команд России в международных соревнованиях, пропаганда и популяризация студенческого спорта [1, С. 431].

В настоящее время достаточно явно прослеживается тенденция консолидации усилий всех заинтересованных лиц и организаций в развитии массовой физкультурнооздоровительной работы и спорта среди молодежи.

Наглядной иллюстрацией к этим словам служит рост количества проектов, связанных с совершенствованием физкультурно-оздоровительной и спортивномассовой работы в студенческой среде. К наиболее популярным из них можно причислить такие, как: «Олимпийское завтра России», «Марафон здоровья и Волна здоровья - «Моя альтернатива», спортивные смены «Беги за мной» и «Команда 2018» Всероссийского молодёжного форума «Селигер 2014», профильные спортивные смены в Федеральном детском оздоровительно-образовательном центре «Смена», клубные турниры АССК России и Всероссийские молодежные проекты «Студенты ГТО» и «Кадровый резерв студенческого спорта» [3, С.17]. 
Наибольший интерес из них представляют собой те, которые являются инновационными, актуальными и созданы для развития молодежного спорта.

Очевидно, что вектор развития студенческого спорта, в котором локомотивом сегодня является спорт высших достижений, нуждается в усилении за счет активизации других направлений, помимо массового спорта, пропагандистской и популяризационной деятельности и т.д.

Необходимо также обратить особое внимание на то, что на современном этапе развития массового студенческого спорта в России крайне острой является проблема, напрямую связанная с подготовкой кадров для того, чтобы обеспечить бесперебойную деятельность спортивных секций и клубов, причем необходимо особо отметить, что решение данной проблемы должно быть возложено на разнообразные образовательные проекты.

Вместе с тем, интересом у студенчества пользуются и проекты, связанные с формированием профессиональных сообществ в среде студенческого спорта.

Пытаясь спрогнозировать дальнейшие перспективы модернизации и совершенствования студенческого спорта, напрашиваются следующие выводы.

В недалеком будущем будет создана широкая и функциональная сеть спортивных клубов в образовательных учреждениях высшего и среднего специального образования, увеличено количество официальных соревнований, лиг, видов спорта для студентов, в общероссийских и региональных федерациях появятся ответственные за работу со студенческим спортом сотрудники (отделы), получит мощный импульс развития региональная сеть РССС, возрастет потенциал и функционал кафедр физического воспитания.

Таким образом, можно сделать общий вывод о том, что, популярность массового студенческого спорта продолжает неуклонно расти не только в Российской Федерации, но также и во всем мире. Возрождение такого движения, как Российские Универсиады, послужило огромным толчком для развития и дальнейшей популяризации студенческого спорта в Российской Федерации. Правительство РФ начало уделять повышенное внимание студенческому спорту, начали развиваться чемпионаты России среди студенческих команд по очень многим видам спорта. Универсиады начали представлять одни из наиболее значимых событий как в рамках спортивной студенческой жизни Российской Федерации, так и в этих же рамках в общемировом масштабе. В данном ключе необходимо упомянуть о том, что большое количество олимпийских чемпионов и призеров являются студентами или же проходят тренировки в клубах при университетах. Именно эти студенты-спортсмены представляют собой сильных конкурентов для профессиональных спортсменов. Соответственно, студенческий резерв можно смело представлять собой в качестве одного из видов ресурсов с точки зрения развития спорта высших достижений.

$$
* * *
$$

1. Об утверждении концепции развития студенческого спорта в Российской Федерации на период до 2025 года: Приказ Министерства спорта РФ от 21.12.2017 №1007 // Сборник официальных документов и материалов Министерства спорта РФ. - Ноябрь 2017. - №11.

2. Авладеев А.А. Концепты развития студенческого спорта в России // Молодой ученый. - 2016. - №10. - C. 430-434.

3. Арсентьев Д.В. Анализ американской модели студенческого спорта // Физическая культура, спорт и здоровье студенческой молодежи в современных условиях: проблемы и перспективы развития: материалы Региональной студенческой научно-практической конференции, 6 апреля 2016 г., г. Екатеринбург / Рос. гос. проф.-пед. ун-т. - Екатеринбург, 2016. - С. 15-19.

4. Генадиева Е.С. Анализ проблем развития студенческого спорта в РФ // Научное сообщество студентов: Междисциплинарные исследования: сб. ст. по мат. XXXIV междунар. студ. науч.-практ. конф. (Россия, г. Новосибирск, 04 декабря 2017 г.). - № 23(34). -Электронный ресурс. - Режим доступа: https://sibac.info/archive/meghdis/23(34).pdf. Дата обращения: 25.01.2018.

5. Журова И.А. Российский студенческий спорт на современном этапе и его реформы // Интерэкспо Гео-Сибирь. - 2013. - Т. 6. - №2. - С. 21-24.

6. Леднев В.А., Первушина Е.А. Тенденции развития студенческого спорта в России // Экономика и управление народным хозяйством. - 2016. - №8 (141). - С. 38-44. 